\title{
The anthropological aspects of dentofacial deformities: A comparison between Indonesian and Dutch cohorts (Aspek antropologi kelainan bentuk dentofasial: Sebuah perbandingan antara kelompok Indonesia dan Belanda)
}

\author{
${ }^{1,2}$ M. Ruslin, ${ }^{2}$ T. Forouzanfar, ${ }^{3}$ I.A. Astuti, ${ }^{4}$ E.S. Soemantri, ${ }^{2}$ D.B. Tuinzing \\ ${ }^{1}$ Department of Oral and Maxillofacial Surgery, Faculty of Dentistry Hasanuddin University, Makassar, Indonesia \\ ${ }^{2}$ Department of Oral and Maxillofacial Surgery/Oral Pathology, VU University Medical Center/Academic Center for \\ Dentistry Amsterdam (ACTA), Amsterdam, The Netherlands \\ ${ }^{3}$ Department of Oral and Maxillofacial Surgery, Faculty of Dentistry Padjadjaran University, Bandung, Indonesia \\ ${ }^{4}$ Department of Orthodontic, Faculty of Dentistry Padjadjaran University, Bandung, Indonesia
}

\begin{abstract}
ABSTRAK
Tujuan dari penelitian ini adalah untuk mengetahui prevalensi kelainan dentofasial dalam kelompok Indonesia dibandingkan dengan kelompok Belanda dan untuk mempelajari aspek antropologis kelainan dentofasial. Kelompok Indonesia meliputi 36 laki-laki dan 50 perempuan dari Bandung. Kelompok Belanda meliputi 1.003 laki-laki dan 1.623 perempuan dari Amsterdam. Sebagian dari kelompok Indonesia berusia kurang dari 30 tahun (93\%) dibandingkan dengan 61,5\% dari kelompok Belanda. Distribusi usia 31-40 tahun terdiri pada kelompok Belanda dibandingkan pasien Indonesia ( $p<0,01)$. Prognatisma mandibula dengan open bite adalah kelainan yang paling umum (46,5\%) di antara kelompok Indonesia dengan usia rata-rata 22,78(SD;6,34). Defisiensi mandibula adalah deformitas umum sedikit $(2,3 \%)$ dengan usia rata-rata 31 (SD;12,73). Sebaliknya, defisiensi mandibula dengan mandibula sudut bidang normal atau rendah adalah kelainan yang paling umum (55,9\%) di antara kelompok Belanda dengan usia rata-rata 30,48 (SD; 1075) dan prognatisma mandibula dengan open bite adalah deformitas paling lazim (3,3\%) dengan usia rata-rata 22,49 (SD;6,20). Dibandingkan dengan penduduk Belanda, penduduk Indonesia lebih banyak prognatisma mandibula $(p<0,01)$ dan lebih sedikit defisiensi mandibula ( $p<0,01)$. Pada kelompok Indonesia, pasien muda mencari bedah ortognatik paling sering untuk memperbaiki masalah fungsional yang berhubungan dengan prognatisma mandibula dengan open bite. Disimpulkan bahwa tingkat keparahan terbesar kelainan dentofasial diamati pada pasien Asia Tenggara.

Kata kunci: antropologi, bedah ortognatik, Asia Tenggara, Eropa Barat
\end{abstract}

\begin{abstract}
The aim of the present study was to investigate the prevalence of dentofacial deformities in an Indonesian cohort compared with a Dutch cohort and to study the anthropological aspects of dentofacial deformities. The Indonesian cohort included 36 male and 50 female patients from Bandung. The Dutch cohort included 1,003 male and 1,623 female patients from Amsterdam. The majority of the Indonesian cohort was less than 30 years old (93\%) compared with $61.5 \%$ of the Dutch cohort. The age distribution of 31-40 years consisted of more Dutch than Indonesian patients $(\mathrm{p}<0.01)$. Mandibular prognathism with an open bite was the most prevalent deformity $(46.5 \%)$ among the Indonesian cohort with a mean age of 22.78 (SD;6.34). Mandibular deficiency was the least prevalent deformity $(2.3 \%)$ with a mean age of 31 (SD;12.73). In contrast, mandibular deficiency with a normal or low mandibular plane angle was the most prevalent deformity (55.9\%) among the Dutch cohort with a mean age of 30.48 (SD;1075) and mandibular prognathism with an open bite was the least prevalent deformity (3.3\%) with a mean age of 22.49 (SD;6.20). Compared to the Dutch population, the Indonesian population consisted of more mandibular prognathism $(\mathrm{p}<0.01)$ and less mandibular deficiency $(\mathrm{p}<0.01)$. In the Indonesian cohort, young patients seek orthognathic surgery most frequently to correct a functional problem associated with mandibular prognathism with an open bite. It was concluded that the greatest severity of dentofacial deformities that are observed in Southeast Asian patients.
\end{abstract}

Key words: anthropological, orthognathic surgery, Southeast Asian, Western European

Koresponden: Muh. Ruslin. E-mail: ruslin_oms@yahoo.com

\section{INTRODUCTION}

Dentofacial deformities, which include the malfunctions of the jaws and teeth, result from an uneven growth pattern between the mandible and maxilla. Such dental deformities appear as mandibular protrusion, maxillary retrusion, or both. ${ }^{1-3}$ Orthognathic surgery is performed on a daily basis across the world to correct dentofacial deformities. Many treatment strategies have been identified in the literature. ${ }^{4,5}$
The prevalence of the number and type of malocclusions vary among the racial groups and nationalities. ${ }^{2}$ Class III malocclusions are more prevalent in Southeast Asian populations. Previous studies have estimated that $15-23 \%$ of individuals from Asian Mongoloid populations exhibit a class III malocclusion. ${ }^{1,6}$ The increased prevalence of Class III malocclusions in these populations is likely to be genetically determined. ${ }^{7,8}$ In contrast, most studies report a lower incidence (approximately 
$1-5 \%)$ of Class III malocclusions in American, European and African Caucasian populations. ${ }^{1,2,7,9}$

The prevalence of the different types of dentofacial deformities has not been studied in an Indonesian population. Therefore, the aim of the present study was to investigate the prevalence of dentofacial deformities in the Indonesian population. The prevalence of dentofacial deformities in an Indonesian cohort was compared with the prevalence of the same deformities within a Dutch cohort to study the anthropological aspects of dentofacial deformities.

\section{MATERIAL AND METHODS \\ Indonesian and Dutch cohorts}

The Indonesian (Bandung) cohort was generated from the hospital and outpatient records from 88 patients who were treated for dentofacial deformities with orthognathic surgery at the Department of Oral and Maxillofacial Surgery, Faculty of Dentistry, Padjadjaran University, Hasan Sadikin General Hospital in Bandung, Indonesia. While the Dutch (Amsterdam) cohort was generated from the hospital and outpatient records from 3,473 patients who were treated for dentofacial deformities with orthognathic surgery at the Department of Oral and Maxillofacial Surgery/Oral Pathology, VU University Medical Center and Academic Centre for Dentistry Amsterdam, The Netherlands; from January 1990 to December 2011.

The inclusion criteria for the study cohorts were the presence of a nonsyndromic dentofacial deformity and a signed informed consent. The exclusion criteria were facial asymmetry and cleft lip and palate. Data from each patient, including gender, age, and deformity classification, were collected from medical records and reviewed and analyzed retrospectively. From the original cohort of patients, 2 Bandung patients and 847 Amsterdam patients were excluded from further study because they did not meet the inclusion/exclusion criteria.

\section{Treatment strategy}

In 1984, the Department of Oral and Maxillofacial Surgery at Hasan Sadikin General Hospital in Bandung, Indonesia and the Department of Oral and Maxillofacial Surgery/Oral Pathology in Amsterdam, The Dutch established a collaboration to apply the same treatment strategies for dentofacial deformities. Approximately $95 \%$ of the patients who seek orthognathic surgery for the treatment of the dentofacial deformities exhibit one of five deformities, as described in detail below. Each deformity has a unique treatment strategy with predictable results about the stability and behavior of the temporomandibular joints (TMJ) and tongue following treatment as well as the potential psychological implications. $^{10}$

\section{Dentofacial deformity definitions}

The 5 dentofacial deformities that are exhibited by $95 \%$ of patients treated with orthognathic surgery are mandibular prognathism, mandibular prognathism with an open bite, mandibular deficiency, relative mandibular deficiency, and absolute mandibular deficiency. The naming convention used for these deformities suggest that all deformities concern the mandible. However, each type includes deformities in other dentofacial structures in addition to the mandible. The specific dentofacial deformities determine the orthognathic surgical strategy as well as the outcomes and expectations. ${ }^{10,11}$

Mandibular prognathism is characterized by a reversed overjet that may arise from a maxillary deficiency, a mandibular prognathism, or both (Fig.1).

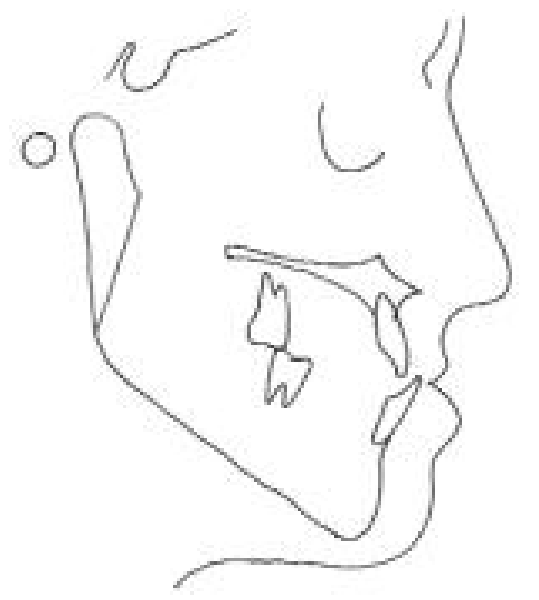

Figure 1 Characteristic deformities of mandibular prognathism with a reversed overjet

Mandibular prognathism with an open bite; this deformity is characterized by mandibular prognathism, as described above, with both a reversed overjet and an open bite that may be due to a maxillary deficiency, a mandibular prognathism, or both. The intraoral magnitude of the reversed overjet and open bite is important. In addition, the transverse relation of the arches is relevant in connection with the function of the tongue (Fig.2).

Mandibular deficiency; this kind of deformity is characterized by a mandibular retrognathism that presents with a convergent facial appearance, an increased overjet, or deep overbite (Fig.3).

Relative mandibular deficiency; this kind of deformity is characterized by a mandible of normal 
size that is retruded secondary to a vertical maxillary hyperplasia (Fig. 4).

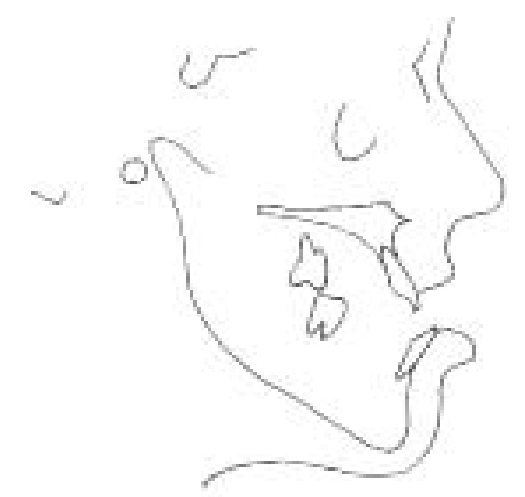

Figure 2 Characteristic deformities of mandibular prognathism with an open bite

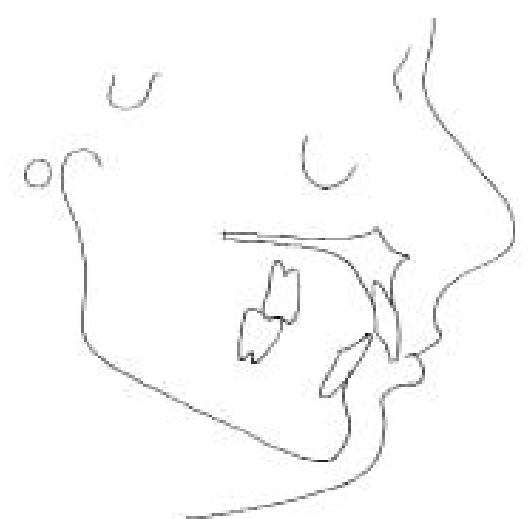

Figure 3 Characteristic deformities of mandibular deficiency

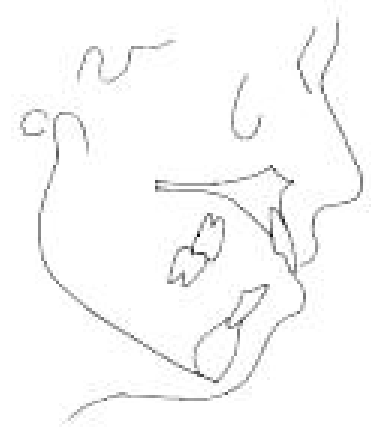

Figure 4 Characteristic deformities of relative mandibular deficiency

Absolute mandibular deficiency; this kind of deformity is characterized by absolute mandibular deficiency, include a divergent facial appearance, an increased sagittal overbite, and the tendency of an open bite, differsignificantly from relative mandibular deficiency. Therefore, the differentiation between these two conditions must be made early in the classification and treatment plan. To distinguish this condition from relative mandibular deficiency, the lateral cephalostat film must be taken in the correct position with the condyles within the articular fossae and with the lips in repose (Fig. 5).

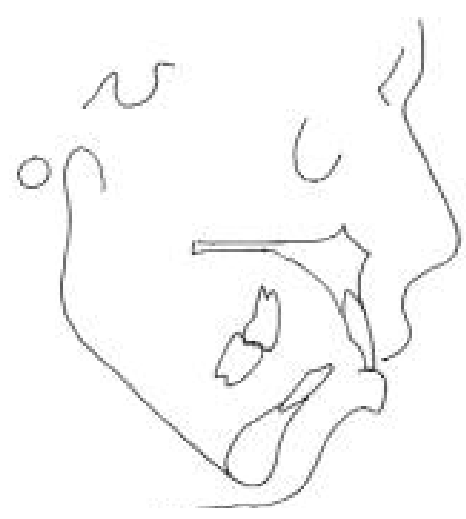

Figure 5 Characteristic deformities of absolute mandibular deficiency

\section{Statistical analysis}

Statistical analyses were conducted with the Statistical Package for Social Sciences (SPSS) version 15.0. The distribution of ages according to gender and the distribution of deformities by gender and age in the Indonesian cohort were analyzed with Mann-Whitney tests. Chi-square tests were used analyzed the distribution of deformities by gender and age in the Dutch cohort.

\section{RESULTS}

The study population consisted of 86 Indonesian patients and 2,626 Dutch patients. The Indonesian cohort included $36(41.9 \%)$ males and $50(58.1 \%)$ females and the Dutch cohortincluded 1,003 (38.2\%) males and 1,623 (61.8\%) females.

Table 1 presents the age distribution according to gender among the Indonesian cohorts and Dutch cohorts. No significant differences could be found concerning the gender distribution. However, in the Dutch population, there were significantly more patients in the age group 31-40 years compared to the Indonesian population $(\mathrm{p}<0.001)$. The majority of the Indonesian cohort (93\%) was under 30 years old, whereas only $61.5 \%$ of the Dutch cohort was under 30 years old.

The distribution of the prevalence of each deformity within the Indonesian and Dutch cohorts are reported in Table 2 and stratified by both gender and age aspect no significant ( $p>0.05)$. Mandibular 
prognathism with an open bite deformity was the most prevalent deformity among the Indonesian cohort (46.5\%) with a mean age of 22.78 (SD;6.34). Mandibular deficiency deformity was the least prevalent deformity among the Indonesian cohort (2.3\%) with a mean age of 31.00 (SD;12.73). In contrast, mandibular deficiency deformity was the most prevalent deformity among the Dutch cohort $(55.9 \%)$ with a mean age of 30.48 (SD;10.75) and mandibular prognathism with an open bite deformity was the least prevalent deformity (3.3\%) with a mean age of 22.49 (SD;6.20) (Table 3). Compared to the Dutch population, the Indonesian population cohort consisted of significantly more mandibular prognathism with an open bite deformity $(\mathrm{p}<0.01)$ and significantly less mandibular deficiency deformity $(\mathrm{p}<0.01)$.

\section{DISCUSSION}

The study of human dentofacial deformities is a fascinating area of a research not only from the perspectives of surgical treatments, complications, and psychological aspects but also because of the anthropological implications. There are studies of anthropological aspects of disease, including the effects of gender, age, ethnic group, and morphology, provides important information for improving patient care, treatment, and health care access. ${ }^{12-16}$

Modig et $\mathrm{al}^{17}$ reported that functional problems were the principal reason that patients seek surgical treatment for dentofacial deformities. In contrast, Finlay et $\mathrm{al}^{18}$ reported that facial appearance was a more significant motivation for seeking surgical treatment $(52 \%)$ compared with functional problems (31\%). A similar result was reported in an Indian population, in which patients cited aesthetics as the primary motivation for orthognathic surgery. ${ }^{19}$ Furthermore, a study by van Steenbergen et $\mathrm{al}^{20}$ reported that the majority of patients who seek orthognathic surgery are young and affluent.

Our comparison between Indonesia (developing nation) and the Netherlands as a developed nation

Table 1 The distribution of ages according to gender among the Indonesian and Dutch cohorts

\begin{tabular}{|c|c|c|c|c|c|c|c|c|c|c|c|c|c|c|}
\hline \multirow{3}{*}{$\begin{array}{l}\text { Range } \\
\text { (years) }\end{array}$} & \multicolumn{6}{|c|}{ Indonesian } & \multirow{3}{*}{$p$ value } & \multicolumn{6}{|c|}{ Dutch } & \multirow{3}{*}{$p$ value } \\
\hline & \multicolumn{2}{|c|}{ Male } & \multicolumn{2}{|c|}{ Female } & \multicolumn{2}{|c|}{ Total } & & \multicolumn{2}{|c|}{ Male } & \multicolumn{2}{|c|}{ Female } & \multicolumn{2}{|c|}{ Total } & \\
\hline & $\mathrm{n}$ & $\%$ & $\mathrm{~N}$ & $\%$ & $\mathrm{n}$ & $\%$ & & $\mathrm{n}$ & $\%$ & $\mathrm{n}$ & $\%$ & $\mathrm{~N}$ & $\%$ & \\
\hline$\leq 10$ & - & - & - & - & - & - & & 2 & 0.2 & 4 & 0.2 & 6 & 0.2 & \\
\hline $11-20$ & 11 & 30.6 & 26 & 52.0 & 37 & 43.0 & & 287 & 28.6 & 454 & 28.0 & 741 & 28.2 & \\
\hline $21-30$ & 24 & 66.7 & 19 & 38.0 & 43 & 50.0 & & 330 & 32.9 & 539 & 33.2 & 869 & 33.1 & \\
\hline $31-40$ & 1 & 2.8 & 4 & 8.0 & 5 & 5.8 & 0.163 & 224 & 22.3 & 387 & 23.8 & 611 & 23.3 & 0.965 \\
\hline $41-50$ & - & - & 1 & 2.0 & 1 & 1.2 & & 128 & 12.8 & 186 & 11.5 & 314 & 12.0 & \\
\hline $51-60$ & - & - & - & - & - & - & & 29 & 2.9 & 44 & 2.7 & 73 & 2.8 & \\
\hline$\geq 61$ & - & - & - & - & - & - & & 3 & 0.3 & 9 & 0.6 & 12 & 0.5 & \\
\hline Total & 36 & 100 & 50 & 100 & 86 & 100 & & 1003 & 100 & 1623 & 100 & 2626 & 100 & \\
\hline
\end{tabular}

Mann-Whitney test; $\mathrm{p}<0.05$ : significant

Table 2 The distribution of deformities in the Indonesian cohort by gender and age

\begin{tabular}{|c|c|c|c|c|c|c|}
\hline \multirow{3}{*}{ Deformities } & \multicolumn{5}{|c|}{ Indonesian } & \multirow{3}{*}{$\begin{array}{c}p \\
\text { value }\end{array}$} \\
\hline & \multirow{2}{*}{$\mathrm{n}$} & \multirow{2}{*}{$\%$} & \multicolumn{2}{|c|}{ Sex } & \multirow{2}{*}{ Mean age (sd) } & \\
\hline & & & Male $(\mathrm{n}, \%)$ & Female $(\mathrm{n}, \%)$ & & \\
\hline A mandibular prognathism & 32 & 37.2 & $12(33.3)$ & $20(40)$ & $21.03(3.89)$ & \\
\hline B mandibular prognathism with an open bite & 40 & 46.5 & $23(63.9)$ & $17(34)$ & $22.78(6.34)$ & \\
\hline $\mathrm{C}$ mandibular deficiency & 2 & 2.3 & - & $2(4)$ & $31.00(12.73)$ & 0.430 \\
\hline D relative mandibular deficiency & 6 & 7 & $1(2.8)$ & $5(10)$ & $24.83(3.82)$ & \\
\hline E absolute mandibular deficiency & 6 & 7 & - & $6(12)$ & $21.67(4.89)$ & \\
\hline
\end{tabular}

Mann Whitney test. $\mathrm{P}<0.05$ : significant

Table 3 The distribution of deformities in the Dutch cohort by gender and age

\begin{tabular}{|c|c|c|c|c|c|c|}
\hline \multirow{3}{*}{ Deformities } & \multicolumn{5}{|c|}{ Dutch } & \multirow{3}{*}{$\begin{array}{c}p \\
\text { value }\end{array}$} \\
\hline & \multirow{2}{*}{$\mathrm{n}$} & \multirow{2}{*}{$\%$} & \multicolumn{2}{|c|}{ Sex } & \multirow{2}{*}{ Mean age (sd) } & \\
\hline & & & Male (n,\%) & Female $(\mathrm{n}, \%)$ & & \\
\hline A mandibular prognathism & 364 & 13.9 & $128(12.8)$ & $236(14.5)$ & $25.80(10.41)$ & \\
\hline B mandibular prognathism with an open bite & 87 & 3.3 & $35(3.5)$ & $52(3.2)$ & $22.49(6.20)$ & \\
\hline C mandibular deficiency & 1467 & 55.9 & $595(59.3)$ & $872(53.7)$ & $30.48(10.75)$ & 0.062 \\
\hline D relative mandibular deficiency & 169 & 6.4 & $57(5.7)$ & $112(7)$ & $23.92(6.73)$ & \\
\hline E absolute mandibular deficiency & 539 & 20.5 & $188(18.7)$ & $351(21.6)$ & $28.36(10.08)$ & \\
\hline
\end{tabular}

Chi Square test. $\mathrm{P}<0.05:$ significant 
shows differences in age and morphology in patients undergoing orthognathic surgery. Because the kind of surgery is categorized as an aesthetic treatment that is not covered by insurance, the majority of Indonesian patients who receive surgical treatment are young, affluent, and/or report functional problems. They have probably high socioeconomic status compared with the patients not seeking surgical treatment. However the present data we are not able to prove this issue.

The gender distribution between the Indonesian cohort and Dutch cohort were similar with a higher prevalence of female patients. These results are similar to the results reported by Modig et $\mathrm{al}^{17}$ in which $55 \%$ of the patients were female. Watanabe et $\mathrm{al}^{8}$ found that mandibular prognathism in the proband was reported more frequently in females (60 patients) compared with males (45 patients). A similar study by Finlay et $\mathrm{al}^{18}$ reported results from a population with $61 \%$ female patients, of which $81 \%$ were single (19\% married). A study by van Steenbergen et al $^{20}$ also found that women comprised the majority of respondents $(75.9 \%)$. The gender disparity in these studies does not necessarily indicate that dentofacial deformities are more prevalent in females compared with males. These results may suggest a selection bias because women may be more concerned with aesthetics and health and may disproportionately seek solutions for their dentofacial deformites compared with males. ${ }^{2,8}$

Although the gender distribution between the Indonesian and Dutch cohorts was similar, the age distribution was significantly skewed toward younger individuals (under 30 years old) in the Indonesian cohort. The ages of the Dutch cohort were more evenly distributed between younger (under 30 years old) and older (over 30 years old) patients. The age ranges of the patients in these cohorts were similar to the age ranges reported by Finlay et $\mathrm{al}^{18}$ who reported an age range between 18 and 60 years old. The age distribution in the Finlay et $\mathrm{al}^{18}$ study was also skewed such that $45 \%$ of the patients were less than 20 years old and $35 \%$ of the patients were between 21 and 30 years old. Furthermore, in that study, most young males reported seeking treatment due to functional problems, whereas most young females reported seeking treatment to improve their self-confidence. In another study, the older female patients reported an improvement in self-esteem following treatment, whereas older male patients reported no changes in eitherself-esteem or depression following a surgical intervention. ${ }^{21}$

Previous studies ${ }^{1,6,7,9}$ have suggested that the severity of dentofacial deformities could be predicted by racial group or nationality. A critical finding of the present study was the differences in the prevalence of five defined dentofacial deformities between the Indonesian and Dutch cohorts. This study reported that mandibular prognathism with an open bite (deformity B) was the most prevalent deformity and mandibular deficiency with a normal or low mandibular plane angle (deformity $\mathrm{C}$ ) was the least prevalent deformity in the Indonesian cohort. In contrast, mandibular deficiency with a normal or low mandibular plane angle was the most prevalent deformity and mandibular prognathism with an open bite was the least prevalent deformity in the Dutch cohort.

These results show a correlation with respect to the severity and type of dentofacial deformities between Southeast Asian and Caucasian populations. A study by Watanabe et $\mathrm{al}^{8}$ showed a high aggregation of Class III mandibular prognathism in Japanese families, which suggests a significantgeneticinfluence. The normal lateral view of the facial structure among Southeast Asian individuals appears flat compared with the normal lateral view among Caucasian individuals, which appears concave. ${ }^{1,22}$ Chang et $\mathrm{al}^{1}$ compared the cranial base configuration on cephalographs between European-American and Taiwanese, Japanese, Korean and Chinese populations and reported a relatively low prevalence of Class III malocclusions among Caucasians compared with a higher prevalence among Asians. Khadka et $\mathrm{al}^{3}$ reported a square face with a wide mandible and/or a wide and prominent zygoma among East Asian populations. Ishii et $\mathrm{al}^{23}$ reported that a Class II Division 1 maxillary protrusion in Japanese girls may represent a vertical problem due to the backward rotation of the mandible. In contrast, a Class II Division 1 maxillary protrusion in Caucasians may indicate a horizontal problem due to the anterior position of the maxilla. Furthermore, Ayoub et $\mathrm{al}^{24}$ reported that there are significant differences within each subgroup of the same race. For example, the craniodentofacial size of the Chinese in Taiwan is significantly larger in males compared with females but their craniodentofacial morphology is similar. According to, Rauso et $\mathrm{al}^{25}$ surgical treatment results in the widening of the alar base, which is found to occur almost universally following maxillary osteotomies. Widening of the alar base is an important consideration for Asian patients because their noses are wider and flatter than the noses of Europeans and Americans. ${ }^{26,27}$

The present study has several shortcomings. The number of patients in the Indonesian cohort was limited compared with the Dutch cohort. Therefore, 
the results could not be stratified over the same age ranges between the two cohorts. In Indonesia, there are four university hospitals with a Department of Oral and Maxillofacial Surgery. Each of these university hospitals treats patients with dentofacial deformities; however, the number of treated patients are not equally distributed among the hospitals. Most patients are treated at the Bandung university hospital, which has been offering orthognathic surgery since 1984. Therefore, our results may not be generalizable to the whole population of Indonesia. Because this study was retrospective, the analysis may include an information bias. However, the results presented in this study are similar to the reports from other studies. Furthermore, the analysis in this report provides important data for improving the treatment plans for orthognathic surgery.

It is concluded that in the Indonesian cohort, young patients seek orthognathic surgery most frequently to correct a functional problem associated with mandibular prognathism with an open bite. These results may reflect the greatest severity of dentofacial deformities that are observed in Southeast Asian patients.

\section{REFERENCES}

1. Ayoub F, Rizk A, Yehya M, Cassia A, Chartouni S, Atiyeh F, et al: Sexual dimorphism of mandibular angle in a Lebanese sample. J Forensic Leg Med 2009; 16:121-4.

2. Bell WH. Modern practice in orthognathic and reconstructive surgery. Vol. 3. Philadelphia: Saunders, 1992:19792110

3. Boeck EM, Lunardi N, Pinto AS, Pizzol KE, Boeck NRJ. Occurrence os skeletal malocclusions in Brazilian patients with dentofacial deformities. Braz Dent J 2011; 22:340-45.

4. Chang HP, Tseng YC, Chang HF. Treatment of mandibular prognathism. J Formos Med Assoc 2006;105:781-790

5. Chung C, Lee Y, Park KH, et al. Nasal changes after surgical correction of Skeletal Class III malocclusion in Koreans. Angle orthod 2008;78:427-432

6. Epker BN, Wolford LM. Dentofacial deformities; surgical-orthodontic correction. St Louis: Mosby, 1980:41-93

7. Farkas LG, Katic MJ, Forrest CR. Comparison of craniofacial measurements of young adult African-American and North American white males and females. Ann Plast Surg 2007;59:692-698

8. Finlay PM, Atkinson JM, Moos KF. Orthognathic surgery: patient expectations; psychological profile and satisfaction with outcome. Br J Oral Maxillofac Surg 1995;33:9-14

9. Flint M. Anthropological perspectives of the menopause and middle age. Maturitas 1982;4:173-180

10. Ishii N, Deguchi T, Hunt NP. Morphological differences in the craniofacial structure between Japanese and Caucasian girls with Class II devision 1 malocclusion. Eur J Orthod 2002;24:61-67.

11. Khadka A, Liu Y, Li J, Zhu S, Luo E, Feng G, Hu J. Changes in quality of life after orthognathic surgery: a comparison based on the involvement of the occlusion. Oral Surg Oral Med Oral Pathol Oral Radiol Endod 2011; 112:719-25.

12. Kitagawa Y, Manabe Y, Oyamada J, Rokutanda A. Morphological deciduous lower first molar teeth. Arch Oral Biol 1996; 41:387-91.

13. Lee LH, Jun JH, Danganan M, Pogrel MA, Kushner H, Lee JS. Orthognathic surgery for the Asian patient and the influence of the surgeon's background on treatment. Int J Oral Maxillofac Surg 2011; 40:458-63.

14. Manabe Y, Oyamada J, Kitagawa Y, Rokutanda A, Kato K, Matsushita T. Dental morphology of the Dawenku Neolithic population in North Cina; implication for the origin and distribution of sinodonty. J Hum Evol 2003; 45:369-80.

15. Milella M, Belcastro MG, Zollikofer CPE, Mariotti V. The effect of age, sex, and physical activity on entheseal morphology in a contemporary Italian skeletal collection. Am J Phys Anthropol 2012; 148:379-88.

16. Modig M, Andersson L, Wardh I. Patients' perception of improvement after orthognathic surgery: pilot study. Br J Oral Maxillofac Surg 2006;44:24-27

17. Naffah, J. Dermatoglyphic analysis: anthropological and medical aspects. Bull N Y Acad Med 1977;53:681-692

18. Narayanan V, Guhan S, Sreekumar K, et al. Self-assessment of facial form oral function and psychosocial function before and after orthognathic surgery: a retrospective study. Indian J Dent Res 2008;19:12-16

19. Nicodemo D, Pereira MD, Ferreira LM. Effect of orthognathic surgery for class III correction on quality of life as measured by SF-36. Int J Oral Maxillofac Surg 2008;37:131-134

20. Rauso R, Gherardini G, Santillo V, et al. Comparison of two techniques of cinch suturing to avoid widening of the base of the nose after Le Fort I osteotomy. Br J Oral Maxillofac Surg 2010;48:356-359

21. Singh GD, McNamara JA Jr, Lozanoff S. Finite-element morphometry of soft tissues in prepubertal Korean and European-Americans with Class III malocclusions. Arch Oral Biol 1999;44:429-436

22. Tang EL. The prevalence of malocclusion amongst Hong Kong male dental students. Br J Orthod 1994;21:57-63

23. Tuinzing DB, Greebe RB, Dorenbos J, Becking AG. Surgical orthodonthics: classification, diagnosis and treatment. Maarssen: Elsevier; 2005. p.23-33.

24. Tuinzing DB, Greebe RB, Dorenbos J, Van der Kwast WAM. Chirurgische orthodontie; diagnose en behandeling. 
Amsterdam: VU Uitgeverij; 1990. p.37-67.

25. Van Steenbergen E, litt MD, Nanda R. Presurgical satisfaction with facial appearance in orthognathic surgery patients. Am J Orthod Dentofacial Orthop 1996;109:653-659

26. Van Vuuren C. A review of the literature on the prevalence of class III malocclusion and mandibular prognathic growth hypotheses. Aust Orthod J 1991;12:23-28

27. Watanabe M, Suda N, Ohyama K. Mandibular prognathism in Japanese families ascertained through orthognathically treated patients. Am J Orthod Dentofacial Orthop 2005; 128:466-470 